Acta Universitatis Nicolai Copernici • Pedagogika XLII/2/2021

Nauki Humanistyczno-Społeczne • Zeszyt 454

DOI: http://dx.doi.org/10.12775/AUNC_PED.2021.017

\author{
Anna Włoch \\ Wydział Nauk Społecznych \\ Uniwersytet Pedagogiczny im. Komisji Edukacji Narodowej \\ w Krakowie \\ ORCID: 0000-0002-5286-8464
}

\title{
Polscy pedagodzy \\ O SZKOLNICTWIE ANGIELSKIM \\ Z TRADYCJI POLSKIEJ PEDAGOGIKI \\ PORÓWNAWCZEJ XX WIEKU
}

\section{Polish Educators on English Education. From the tradition of Polish Comparative Education of the $20^{\text {th }}$ century}

\begin{abstract}
Streszczenie
Celem artykułu jest zaprezentowanie rozwoju polskiej pedagogiki porównawczej w XX wieku. Rosnące zainteresowanie badaniami porównawczymi wśród polskich historyków wychowania i pedagogów w latach 60. XX wie$\mathrm{ku}$ zostało przedstawione poprzez ukazanie specyfiki angielskiego systemu oświatowego. Rozwój pedagogiki naukowej w Polsce znacząco zwiększył także zainteresowanie innymi systemami edukacyjnymi w Europie. Publikowanie opracowań o szkołach angielskich i historii edukacji w Wielkiej Brytanii było bardzo oryginalnym podejściem i cieszyło się dużym uznaniem wśród polskich uczonych. Wielu znanych polskich pedagogów i historyków wychowania (poza Bogdanem Nawroczyńskim) jest słabo znanych ze swoich osiągnięć w obszarze pedagogiki porównawczej.
\end{abstract}


Pierwsza część artykułu przedstawia wkład B. Nawroczyńskiego w rozwój polskiej pedagogiki porównawczej. Analiza wyników badań wskazuje, że publikacje polskich autorów: Zygmunta Kukulskiego, Jana Konopnickiego i Karola Kotłowskiego z lat czterdziestych i sześćdziesiątych nie straciły na aktualności, powinny być wzorem rzetelności naukowej i kompendium wiedzy o historii szkolnictwa w Anglii. W badaniach wykorzystano metodę analizy dokumentów, oryginalnych publikacji polskich autorów zajmujących się angielskim szkolnictwem.

Słowa kluczowe: angielskie szkolnictwo, angielski system edukacyjny, polscy komparatyści, polscy pedagodzy, polscy historycy wychowania.

\begin{abstract}
The aim of the article is to present the development of Polish comparative education in the $20^{\text {th }}$ century. Growing interest in comparative research in the 1960s among well-known Polish historians of education and educators was presented by showing the specifics of English school system. The development of scientific pedagogy in Poland has significantly increased the interest in other educational systems in Europe. The publication of studies on English schools and the history of education in the United Kingdom was very original and enjoyed great recognition among Polish scholars. Outstanding Polish educators and historians of education (except for Bogdan Nawroczyński) are rarely known for their achievements in the field of comparative education. The first part of the article presents the contribution of B. Nawroczyński to the development of Polish comparative education. The article proves that the publications of Polish authors: Zygmunt Kukulski, Jan Konopnicki and Karol Kotłowski from the 1940s and 1960s did not lose their relevance, they should be a model of scientific reliability and a compendium of knowledge about the history of education in England. The study used the method of documental analysis, original publications of Polish authors dealing with English education.
\end{abstract}

Key words: English education, English educational system, Polish comparativists, Polish educationalists, Polish historians of education. 


\section{Wprowadzenie}

TTspółcześnie w polskiej literaturze pedagogicznej specyfikę angielskiego szkolnictwa przybliżają przede wszystkim tacy autorzy jak: Eugenia Potulicka oraz młodsze pokolenie badaczy: Agnieszka Gromkowska-Melosik, Tomasz Gmerek, czy Daria Hejwosz-Gromkowska, Alina Matlakiewicz ${ }^{1}$. Wymienieni autorzy (wywodzący się z poznańskiej szkoły badań porównawczych E. Potulickiej i Zbyszko Melosika) swoje analizy porównawcze opierają na teoriach i modelach właściwych dla socjologii edukacji, przybliżając polskiemu czytelnikowi współczesne, złożone problemy elitarności angielskiego szkolnictwa średniego, rolę szkolnictwa w tworzeniu struktury społecznej czy też kwestię edukacji obywatelskiej w Wielkiej Brytanii. Warto wspomnieć, że przed wejściem Polski do Unii Europejskiej wydawano również publikacje, które między innymi poruszały problematykę angielskiego szkolnictwa, ale z uwagi na kolejne reformy systemów edukacji, opracowania te są już mocno zdezaktualizowane ${ }^{2}$. W najnowszych polskich publikacjach na temat angielskiego szkolnictwa dominują zdecydowanie analizy socjologiczne, historyczny aspekt rozwoju tego syste-

${ }^{1}$ Por: E. Potulicka, System edukacji $w$ Wielkiej Brytanii, w: Systemy edukacji $w$ krajach europejskich, red. naukowa E. Potulicka, D. Hildebrandt-Wypych, C. Czech-Włodarczyk, Kraków 2012, s. 341-384; Agnieszka Gromkowska-Melosik, Elitarne szkolnictwo średnie. Między reprodukcją społeczno-kulturowa a ruchliwościq konkurencyjną, Poznań 2015; T. Gmerek, Edukacja i nierówności społeczne. Studium porównawcze na przykładzie Anglii, Hiszpanii i Rosji, Kraków 2011; D. Hejwosz-Gromkowska, Edukacja obywatelska we wspótczesnej Anglii: studium socjopedagogiczne, Poznań 2019; A. Matlakiewicz, Edukacja dorostych $w$ Wielkiej Brytanii, Warszawa 2003.

2 Por: E. Potulicka, Geneza reformy edukacji w Anglii i Walii z roku 1988, Poznań-Toruń 1993; D. Dziewulak, Polityka oświatowa Wspólnoty Europejskiej, Warszawa 1995; D. Dziewulak, Systemy szkolne Unii Europejskiej, Warszawa 1997; R. Pachociński, Wspótczesne systemy edukacyjne, Warszawa 2000; W. Rabczuk, Szkolnictwo prywatne w Europie Zachodniej $i$ w Polsce, Warszawa 1992; W. Rabczuk, Polityka edukacyjna Unii Europejskiej na tle przemian w szkolnictwie krajów członkowskich, Warszawa 1994; W. Rabczuk, Polityka edukacyjna Unii Europejskiej wobec imigrantów oraz mniejszości narodowych i etnicznych, Warszawa 2002. 
mu edukacji stanowi jedynie tło i jest bardzo ograniczany. Szkoda, że koncepcja ścisłego łączenia pedagogiki porównawczej z historią wychowania, propagowana przez klasyka polskiej pedagogiki, który znacząco przyczynił się także do rozwoju komparatystyki w Polsce w latach 60. XX wieku - Bogdana Nawroczyńskiego ${ }^{3}$, nie znajduje wielu naśladowców. Zwolennikami powrotu do pedagogiki porównawczej, wyrosłej ze szkoły B. Nawroczyńskiego są obecnie Renata Nowakowska-Siuta ${ }^{4}$ oraz Bogusław Śliwerski ${ }^{5}$.

Jedyną publikacją wydaną w pierwszej dekadzie XXI wieku, która niezwykle drobiazgowo ukazuje historię rozwoju pedagogiki porównawczej na tle m. in. przemian XIX-wiecznego szkolnictwa w Anglii, jest rozprawa autorstwa Józefa Miąso ${ }^{6}$. Autor ten prezentuje reformy, jakim podlegało francuskie, niemieckie oraz angielskie szkolnictwo wszystkich szczebli w XIX wieku, jak również, co stanowi o oryginalności tej publikacji, wskazuje na dokonania angielskich inspektorów szkolnych: Matthew Arnolda (1822-1888) i jego następców Thomasa Darlingtona (1864-1908) oraz Roberta Moranta (1863-1920) w rozwoju europejskiej pedagogiki porównawczej.

Celem niniejszej publikacji jest ukazanie rozwoju polskiej pedagogiki porównawczej w XX wieku z perspektywy analiz angielskiego szkolnictwa, których to autorami byli znani historycy wychowania i pedagodzy, tacy jak: Zygmunt Kukulski, Jan Konopnicki oraz Karol Kotłowski.

3 Zob.: B. Nawroczyński, Pedagogika porównawcza, „Kwartalnik Pedagogiczny”, 1962 nr 1, s. 29-47; B. Nawroczyński, Przedmiot i metoda pedagogiki porównawczej, „Studia Pedagogiczne”, 1972 t. XXVI, s. 5-18.

${ }^{4}$ R. Nowakowska-Siuta, Pedagogika porównawcza. Problemy, stan badań i perspektywy rozwoju, Kraków 2014, s. 18-22.

5 B. Śliwerski, Ponadczasowa doniosłość pedagogiki porównawczej Bogdana Nawroczyńskiego, „Studia Edukacyjne”, 2018 nr 47, s. 21-32.

6 J. Miąso, Szkolnictwo w XIX-wiecznej Europie i początki pedagogiki porównawczej w Anglii, „Rozprawy z Dziejów Oświaty”, 2009 t. XLVI, s. 85-146.

7 Historia angielskiego szkolnictwa była także przedmiotem badań i analiz Józefa Miąso, których wyniki opublikował w „Rozprawach z Dziejów Oświaty”. Na uwagę zasługują zwłaszcza publikacje: Oświata dorosłych w Wielkiej Brytanii pierwszej połowy XIX wieku, „Rozprawy z Dziejów Oświaty”, 1980 t. 23, s. 101-124; Geneza i rozwój uniwersytetów powszechnych w Anglii, „Rozprawy z Dziejów Oświaty", 1984 t. 26, s. 109-140. 
Faktem jest, że polska pedagogika porównawcza, mimo tradycji sięgających początków XIX wieku ${ }^{8}$, faktycznie zaczęła się rozwijać od lat 60. XX wieku, kiedy to nurt badań porównawczych zaczął propagować w Uniwersytecie Warszawskim B. Nawroczyński. Na uwagę zasługują również publikacje przebywającego na emigracji w czasie drugiej wojny światowej w Wielkiej Brytanii profesora pedagogiki KUL Z. Kukulskiego oraz głównego organizatora edukacji polskich nauczycieli na obczyźnie - Jana Konopnickiego. Wymienieni historycy wychowania i pedagodzy, jedynie poza B. Nawroczyńskim są mało znani ze swoich prac z obszaru pedagogiki porównawczej. Polska komparatystyka ma bogatą tradycję, która zasługuje na należne uznanie oraz przypomnienie jej twórców i ich naukowych dokonań.

Angielskie szkolnictwo znacząco różni się od innych europejskich systemów edukacyjnych, jest rezultatem odmiennej tradycji i historii tego kraju. Zrozumienie zawiłości funkcjonowania różnych typów szkół, przeznaczonych dla konkretnych warstw społecznych, odmienna droga angielskiego społeczeństwa do powszechnej edukacji pod kontrolą państwa, wymagało od polskich historyków wychowania i pedagogów bardzo dobrej znajomości angielskiej tradycji i historii. Publikacje Z. Kukulskiego, J. Konopnickiego i K. Kotłowskiego, wyróżnia wnikliwość w ukazaniu ewolucji angielskiego systemu szkolnego, a przy tym doskonała znajomość angielskiej kultury i mentalności angielskiego społeczeństwa. Sam fakt podjęcia badań komparatystycznych nad szkolnictwem w Wielkiej Brytanii przez polskich autorów, świadczyć może o ich szerokiej wiedzy z zakresu historii edukacji w Europie i chęci przybliżenia polskim pedagogom i nauczycielom oryginalności tego systemu szkolnego. Anglia może się również poszczycić znaczącym wkładem w rozwój odrębnej dyscypliny badań, jak ujmowano w XX wieku pedagogikę porównawczą, dzięki takim wybitnym postaciom, jak Mi-

8 Wojciech Szweykowski jako pierwszy opublikował w 1808 roku w Warszawie pracę zatytułowaną Uwagi nad wyższymi szkołami polskimi w porównaniu do niemieckich, w której przybliżył specyfikę działalności gimnazjów w Berlinie. Por. W. Szwejkowski, Uwagi nad wyższymi szkołami polskimi w porównaniu do niemieckich, Warszawa 18018, s. 14-63,w: Źródła do dziejów wychowania i szkolnictwa w Polsce z doby Izby Edukacji Publicznej 1807-1812, red. Z. Kukulski, Lublin 1931. 
chael E. Sadler (1861-1943) i Nicholas Hans (1888-1969), którzy stworzyli podstawy metodologiczne badań porównawczych. Orędownikiem i propagatorem koncepcji M. Sadlera był w Polsce właśnie B. Nawroczyński.

\section{Bogdan Nawroczyński (1882-1974) i jego wkład w rozwój polskiej pedagogiki porównawczej}

Na gruncie polskiej pedagogiki szczególnym propagatorem badań komparatystycznych był B. Nawroczyński, który tym obszarem badań zajmował się, gdy powrócił do pracy naukowej w Uniwersytecie Warszawskim w 1957 roku (w 1948 roku został wydalony z uczelni z powodów politycznych) ${ }^{9}$. Rozpoczął wówczas działalność naukową w nowej dziedzinie - pedagogice porównawczej, stając się głównym inicjatorem badań w tym obszarze i skupiając wokół siebie grono pracowników, którzy przygotowali pierwsze monografie zagranicznych systemów edukacyjnych. Pod kierunkiem naukowym B. Nawroczyńskiego w Uniwersytecie Warszawskim napisane zostały i obronione pierwsze prace doktorskie z zakresu pedagogiki porównawczej (m.in. Anny Mońki-Stanikowej i Tadeusza J. Wilocha). W gronie polskich badaczy, którzy zajmowali się naukowo analizą angielskiego szkolnictwa B. Nawroczyński znalazł się nieprzypadkowo. Przede wszystkim był on wielkim zwolennikiem metody badań komparatystycznych, której autorem był M. E. Sadler, czemu dawał wyraz w niemal każdej swojej publikacji z pedagogiki porównawczej. Wprawdzie Nawroczyński nie jest autorem żadnej publikacji na temat szkolnictwa w Wielkiej Brytanii, nie mniej jednak dzięki niemu popularyzowane były w Polsce koncepcje metodologiczne badań porównawczych angielskich twórców. Ponadto B. Nawroczyński konsultował przygotowanie niektórych publikacji o szkolnictwie w Anglii, jak na przykład monografię autorstwa Jadwigi Lorii ${ }^{10}$.

9 A. Mońka-Stanikowa, Bogdan Nawroczyński - Człowiek i Dzieło, w: Bogdan Nawroczyński - uczony, humanista, wychowawca, red. naukowa A. Mońka-Stanikowa, S. Mieszalski, A. A. Kotusiewicz, Warszawa 1996, s. 22-23.

10 J. Loria, Szkolnictwo $w$ Anglii i jego tradycje, Wrocław-Warszawa-Kraków 1964, s. 5. 
B. Nawroczyński podkreślał, że za ojca pedagogiki porównawczej należy uznać Marc-Antoine’a Jullien'a de Paris, autora broszury pt. „Szkice i przygotowania przedwstępne do pracy o wychowaniu porównawczym”, wydanej w 1817 roku. Wielkie zasługi w odkryciu na nowo dokonań M.-A. Jullien'a de Paris miał P. Rosselló, którego B. Nawroczyński uważał za największy, obok M. E. Sadlera autorytet europejskiej pedagogiki porównawczej, wskazując jednocześnie, że komparatystyka edukacyjna najprężniej rozwija się w Stanach Zjednoczonych ${ }^{11}$.

Był on zwolennikiem ścisłego łączenia pedagogiki porównawczej z historią wychowania, a więc koncepcji, za którą opowiadał się M. E. Sadler. W artykule opublikowanym w „Kwartalniku Pedagogicznym" w 1962 roku pisał, że monografia z zakresu pedagogiki porównawczej powinna przedstawiać nie tylko szczegółowy opis danego systemu oświaty, czy też szkoły, ale przede wszystkim powinna dawać wytłumaczenie takiego stanu rzeczy ${ }^{12}$. Powołując się na M. E. Sadlera pisał, że każdy, kto bada obcy system wychowania powinien starać się niejako wniknąć w „nienamacalną siłę duchową”, która stanowi filar każdego systemu wychowawczego lub szkolnego i decyduje o jego skuteczności. Należy pamiętać, że konkretny system edukacyjny jest zawsze wytworem danej kultury, specyficznym dla danego narodu. Kontekst kulturowy jest niezwykle ważnym czynnikiem dla każdego komparatysty, którego w żadnej mierze nie wolno pomijać w naukowych analizach ${ }^{13}$.

Dla B. Nawroczyńskiego pedagogika porównawcza jest nauką „czystą", podobnie jak nauki przyrodnicze, ponieważ bada to co jest, a nie to co być powinno. Ponadto jest też nauką indukcyjną, zaczyna się od opisu następstw, aby do nich dopiero dobierać racje ogólne. Odwoływał się przy tym do dokonań P. Rosselló, któremu udało się po latach pracy naukowej sformułować dwie zasady determinujące prądy w wychowaniu (I Szkoła i życie społeczne znajdują się w stosunku wzajemnego na siebie oddziaływania; II Fakty pedagogiczne znajdują się w stosunku wzajemnej od siebie zależności) oraz przyczyny, które prawdopodobnie determinują owe prądy w wychowaniu. Doszedł on ostatecznie do

\footnotetext{
11 B. Nawroczyński, Przedmiot i metoda..., s. 5-8.

12 B. Nawroczyński, Pedagogika porównawcza..., s. 29-47.

13 Tamże, s. 36-37.
} 
wniosku, iż celem nadrzędnym badań porównawczych jest stawianie prognozy $^{14}$. B. Nawroczyński wyraźnie wskazuje na użyteczność badań i analiz komparatystycznych. Mając wiedzę o tym, jak funkcjonują systemy edukacyjne $\mathrm{w}$ innych krajach, które rozwiązania się sprawdzają, można próbować reformować własny system edukacyjny, wykorzystując doświadczenia innych państw. Ponadto można prognozować, że szkolnictwo w danym sektorze będzie się rozwijało w pożądanym kierunku, o ile wprowadzi się konkretne rozwiązania na poziomie instytucjonalnym.

Pierwszą i najważniejszą publikacją B. Nawroczyńskiego w obszarze pedagogiki porównawczej była monografia „O szkolnictwie francuskim”, wydana w 1961 roku $^{15}$. W Przedmowie autor wskazał na konieczność opracowywania i publikowania prac z zakresu pedagogiki porównawczej, gdyż takowych w Polsce wydawano wówczas mało. Szczegółowo przedstawił stan badań w tej dziedzinie, wymieniając tłumaczenie z języka angielskiego na polski znaczącej monografii Petera Sandiforda pt. „Szkolnictwo angielskie”, którego dokonał Władysław Gumplowicz, czy też publikacje Żanny Kormanowej pt. „Reforma szkolnictwa w Anglii i we Francji”16 oraz Karola Kotłowskiego pt. „Szkoła angielska po drugiej wojnie światowej”. B. Nawroczyński otwarcie przyznawał, że: szkolnictwo każdego kraju winno być przede wszystkim przystosowane do jego własnych warunków i potrzeb ${ }^{17}$, ale jednocześnie wprowadzane reformy systemu edukacji nie powinny się dokonywać w izolacji od reszty świata, od ogólnoświatowych tendencji w rozwoju edukacji. Ważną funkcją komparatystyki jest informowanie pedagogów opracowujących kierunki rozwoju oświaty, ale także i opinii publicznej ${ }^{18}$.

Na uwagę zasługuje także wyjątkowy styl pisarstwa B. Nawroczyńskiego, który jest typowo angielski. Konkretne treści przedstawia on w sposób niebanalny, narracja jest lekka, język prosty, a wywód lo-

14 Tamże, s. 11-15.

15 B. Nawroczyński, O szkolnictwie francuskim, Warszawa 1961.

16 Publikacja Ż. Kormanowej o szkolnictwie angielskim została w tym opracowaniu pominięta.

17 B. Nawroczyński, O szkolnictwie francuskim, s. 6.

18 Tamże, s. 7. 
giczny. Posługuje się przy tym B. Nawroczyński licznymi przykładami, aby dodatkowo zobrazować swój punkt widzenia. Jego publikacje z pedagogiki porównawczej dostarczają wiele cennych, uporządkowanych informacji, ale nie są przy tym przeładowane aparatem naukowym. W końcu B. Nawroczyński miał za wzór swojego mistrza - Kazimierza Twardowskiego, światowej sławy logika.

\section{Zygmunt Bolesław Kukulski (1890-1944) o angielskich Public Schools}

Zygmunt Kukulski jest znany jako badacz dziejów polskiego szkolnictwa, mający szczególne zasługi dla instytucjonalnego rozwoju pedagogiki w Katolickim Uniwersytecie Lubelskim. Zdecydowanie mniej znana jest natomiast jego działalność naukowa w obszarze pedagogiki porównawczej z czasów jego emigracji w Wielkiej Brytanii.

Wybuch drugiej wojny światowej zastał Z. Kukulskiego wracającego ze Stanów Zjednoczonych. Nie mając możliwości powrotu do kraju, pozostał on w Anglii. Początkowo przebywał w Londynie, a następnie przeniósł się do Szkocji, gdzie w latach 1943-1944 prowadził wykłady z historii wychowania na kursach dla nauczycieli, którzy odbywali służbę wojskową oraz na zorganizowanym w 1943 roku Studium Pedagogicznym przy Uniwersytecie w Edynburgu ${ }^{19}$. W tym czasie publikował również artykuły i rozprawy naukowe. Na szczególną uwagę zasługuje publikacja wydana w 1942 roku w Londynie pt. „Tak zwane Public Schools w Wielkiej Brytanii" ${ }^{20}$, w której zaprezentował fenomen angielskich elitarnych szkół elementarnych i średnich. W dorobku Z. Kukulskiego znajduje się także nieopublikowana rozprawa pt. „Na-

19 W. Chmielewski, Przygotowanie kadr oświatowych na uchodźstwie $w$ latach 1941-1948, Warszawa 2013, s. 40; J. Draus, Zygmunt Kukulski (1890-1944), „Roczniki Nauk Społecznych”, 1989 t. XVII, z. 2, s. 16-18.

20 Z. Kukulski, Tak zwane „Public Schools” w Wielkiej Brytanii, „Nauka i Wychowanie”, z. 1, Londyn 1942, ss. 69, https://pbc.gda.pl/dlibra/publication/39163/ edition/65418/content?\&meta-lang=pl (dostęp: 28.04.2020). (dostęp, 09.02.2021). 
uczyciel angielski i jego kształcenie na tle doby obecnej"21. Do publikacji z zakresu komparatystyki edukacyjnej należy zaliczyć również artykuł pt. „Brytyjski ideał pedagogiczny”, który ukazał się w numerze pierwszym „Przeglądu Pedagogicznego” w 1941 roku. Niestety do dnia dzisiejszego zachowały się jedynie cztery egzemplarze tego periodyku (dwa w bibliotekach amerykańskich, jeden w Londynie i jeden w archiwum Uniwersytetu w Edynburgu) ${ }^{22}$.

Jak podaje Katarzyna Wołk, działalność naukowa z czasów emigracji Z. Kukulskiego w Szkocji jest słabo znana. Wiele cennych informacji o jego badaniach naukowych, w tym również w obszarze pedagogiki porównawczej można wynieść z lektury prywatnej korespondencji Z. Kukulskiego, która znajduje się w Archiwum Instytutu Polskiego i Muzeum im. gen. Sikorskiego w Londynie (The Polish Instiute and Sikorski Museum). Z listów Z. Kukulskiego, które opublikowała K. Wołk można dowiedzieć się, iż podjął on starania, aby zorganizować sobie warsztat badawczy, odwiedził niektóre najlepsze angielskie szkoły, nawiązał współpracę z bibliotekami uniwersyteckimi, chcąc lepiej poznać specyfikę angielskiego i szkockiego szkolnictwa ${ }^{23}$. Z listu Z. Kukulskiego z grudnia 1940 wynika, iż zwiedził pobieżnie uniwersytety w Oksfordzie i Cambridge oraz słynne Public Schools: Eton College, Harrow School oraz szkockie szkoły w Edynburgu, Glasgow i Aberdeen. Nawiązanie współpracy z licznymi szkołami oraz uniwersytetami zapewniły mu dostęp do roczników edukacyjnych oraz programów studiów, które później wnikliwie analizował² ${ }^{24}$.

Z. Kukulski poza pracą w charakterze wykładowcy zaczął prowadzić badania naukowe w nowym dla siebie obszarze, jakim była pedagogika porównawcza. W badaniach nad angielskim i szkockim szkol-

21 J. Dobrzański, Wspomnienie o Zygmuncie Kukulskim, „Roczniki Humanistyczne", 1950-1951 nr 2-3, s. 364-365.

22 Zob.: K. Wołk, Zygmunt Bolesław Kukulski (1890-1944). Pedagog, wychowawca i społecznik, Lublin 2018, s. 17; Z. Kukulski, Brytyjski ideał wychowawczy, „Przegląd Pedagogiczny”, 1941 nr 1, s. 6-8.

${ }^{23}$ K. Wołk, Listy Zygmunta Kukulskiego z okresu szkockiego źródłem badań biograficznych, „Biografistyka Pedagogiczna”, 2017 R. 2, nr 1, s. 397-398.

24 Przedruk wybranych czterech listów Zygmunta Kukulskiego zamieszczony został w artykule K. Wołk, Listy Zygmunta Kukulskiego..., s. 400-404. 
nictwem ${ }^{25}$, wykorzystywał nie tylko analizę dokumentów, ale również prowadził badania terenowe (zwiedzał szkoły, prowadził wywiady z kadrą pedagogiczną), czyli stosował typowe metody badawcze właściwe dla komparatystyki edukacyjnej. Z całą pewnością pomagała mu w tym przedsięwzięciu znajomość historii wychowania w Europie, ale i fakt, iż mieszkając na Wyspach Brytyjskich miał najlepszą okazję, aby poznać bliżej angielską oraz szkocką kulturę i tradycję.

Zaangażowanie Z. Kukulskiego w edukację polskich nauczycieli na obczyźnie było znaczące. Był on aktywnym uczestnikiem zjazdu polskich nauczycieli w Perth w Szkocji w 1941 roku, gdzie wygłosił referat o korzyściach ze znajomości szkół brytyjskich dla polskich nauczycie$1 i^{26}$. Z. Kukulski upatrywał więc w uprawianiu pedagogiki porównawczej szansę na lepsze poznanie oryginalności szkolnictwa w Wielkiej Brytanii, mając nadzieję, że wiedza ta może okazać się przydatna dla nauczycieli i działaczy oświatowych przy odbudowywaniu polskiego szkolnictwa po zakończeniu wojny.

Publikację pt. „Tak zwane „Public Schools” w Wielkiej Brytanii” Z. Kukulski miał szansę wydać w 1942 roku, będąc stypendystą Funduszu Kultury Narodowej ${ }^{27}$. Jest to jedno z pierwszych opracowań w języku polskim, przybliżające czytelnikowi wiedzę o bogatej tradycji najlepszych, elitarnych, prywatnych szkół elementarnych i średnich, jakie działają na Wyspach Brytyjskich, w tym najstarszych istniejących od kilku stuleci. Kukulski nie tylko opisał działalność najbardziej znanych Public Schools, takich jak: Winchester College, Eton College, St. Paul's School, Shrewsbury School, Westminster School, Merchant Taylors' School, Rugby School, Harrow School i Charterhouse School, które zali-

25 System edukacji w Wielkiej Brytanii jest zdecentralizowany, w zasadzie funkcjonują trzy systemy edukacyjne właściwe dla historycznych części Zjednoczonego Królestwa: Anglii i Walii, Szkocji oraz Irlandii Północnej. Zygmunt Kukulski prowadził badania wyłącznie nad szkołami angielskimi i szkockimi.

26 J. Draus, Zygmunt Kukulski..., s. 16-17.

27 Jan Draus jako datę wydania tej publikacji podaje rok 1941, ale rzeczywiście wydana ona została w roku 1942. Z. Kukulski, Tak zwane „Public Schools”... https://pbc.gda.pl/dlibra/publication/39163/edition/65418/content?\&meta-lan$\mathrm{g}=\mathrm{pl}$ (dostęp: 09.02.2021); J. Draus, Zygmunt Kukulski, s. 17. 
cza się to tzw. „starych” Public Schools, ale także swoją uwagę skupił na równie dobrych szkołach katolickich oraz nowszych Public Schools ${ }^{28}$.

Przedmowę do tej publikacji napisał gen. Józef Haller, który podkreślił, iż jest to pierwsze opracowanie szkolnictwa angielskiego i szkockiego w języku polskim. Podkreślając walory tej publikacji, jednocześnie zwrócił uwagę, że jego życzeniem jest, aby młodzi polscy pedagodzy poznali różnorodność szkolnictwa angielskiego i szkockiego, które nie opiera się na utartych schematach. Gen. J. Haller z uznaniem odniósł się także do celów badań komparatystycznych, pisząc: chciałbym przez porównawcze studia wyedukować najlepsze metody nauczania $i$ wychowania, do czego może posłużyć niniejszy podręcznik Pana Profesora ${ }^{29}$.

Przybliżając polskiemu czytelnikowi fenomen angielskich Public Schools, Z. Kukulski w pierwszej części swojej publikacji dokonał charakterystyki różnych typów instytucji edukacyjnych, jakie działały w Wielkiej Brytanii oraz opisał pokrótce brytyjską drabinę szkolną. Następnie przedstawił historię tych szkół, od powstania pierwszych placówek już w epoce średniowiecza, poprzez zmiany społeczne jakie zaszły w XVIII wieku, reformy Public Schools z drugiej połowy XIX wieku, aż do rozwiązań wprowadzanych w ich organizacji po ogłoszeniu kolejnych raportów Board of Education (Wydziału Edukacji, pełniącego rolę ministerstwa oświaty). Z. Kukulski charakteryzował Public Schools następująco: Dzisiejsze „Public Schools”, nieoglądające się na pomoc rzqdową i pozostające z dala od kontroli państwowej, mają swój rodowód $w$ archiwum przeszłości. Do wielkich zakładów starych przybyły z czasem i nowsze, a pod jej skrzydła opiekuńcze uciekły się i niektóre „Grammar Schools” bez „Stateaid”. Reprezentuja one rodzaj wychowania, który stał się alfa i omega brytyjskich szczytów społecznych, opartych na szlachectwie i bogactwie ${ }^{30}$. Podkreślił tym samym, na czym polega wyjątkowość edukacji w Anglii, a mianowicie między innymi na istnieniu swoistego fenomenu szkół prywatnych, które są niezależne od państwa. Szkoły te wybierają dla swoich dzieci przedstawiciele angielskiej

28 Z. Kukulski, Tak zwane „Public Schools”..., s. 35-55.

29 J. Haller, Zamiast przedmowy, w: Z. Kukulski, Tak zwane „Public Schools”..., s. 5.

30 Z. Kukulski, Tak zwane „Public Schools”..., s. 8. 
arystokracji oraz zamożnej klasy średniej. Wielką popularnością cieszą się szkoły z internatem, osobne dla chłopców i osobne dla dziewcząt. W każdej z Public Schools mamy do czynienia z promowaniem konkretnego ideału wychowania.

Z. Kukulski zaznaczył, że to właśnie Anglia bardzo długo stała na gruncie wolności indywidualnej w sferze wychowania, opierając się tendencjom podporządkowania szkolnictwa państwu, co było z kolei wyrazem liberalizmu kontynentalnego $\mathrm{w}$ wielu krajach europejskich pod koniec XVIII wieku. Aż do 1870 roku w Anglii nie podjęto żadnych istotnych decyzji, które zmierzałyby w kierunku zorganizowania państwowego systemu edukacji ${ }^{31}$. To w 1870 roku przyjęto w Anglii ustawę, którą opracował liberał William E. Foster, zwaną Elementary Education Act. Wprawdzie ustawa ta nie wprowadziła obowiązku szkolnego ani bezpłatnego dostępu do szkół, to jednak była istotnym krokiem w kierunku utworzenia w Anglii państwowego systemu edukacji. Dokument ten był formą kompromisu pomiędzy liberałami a przedstawicielami Kościoła anglikańskiego, którzy byli przeciwni wszelkim zmianom w szkolnictwie $^{32}$. Szkoła w całej Anglii stała się rzeczywiście obowiązkowa dopiero w 1880 roku, gdy w wyniku działań rad szkolnych (schoolboards) sieć szkół znacznie się poszerzyła, a opłaty za naukę zostały istotnie zredukowane lub w całości zniesione ${ }^{33}$.

W niezwykle interesujący sposób tłumaczy Z. Kukulski genezę reform Public Schools z drugiej połowy XIX wieku, wskazując na Thomasa Arnolda (dyrektora słynnej Rugby School), jako inicjatora nowej drogi dla tych tradycyjnych szkół, która to miała pogodzić ideę klasycznego wykształcenia z przygotowaniem człowieka interesu (man of affairs), odpowiadając tym samym na potrzeby zmieniającego się społeczeństwa ${ }^{34}$. Z. Kukulski docenił wkład T. Arnolda w modernizację programów nauczania, akcentowanie wychowania moralnego, kształtowanie charakteru, postawy chrześcijańskiego gentelmana oraz na

31 Tamże, s. 19.

32 J. Miąso, Szkolnictwo w XIX-wiecznej Europie..., s. 102-103.

33 Tamże, s. 103.

34 Z. Kukulski, Tak zwane „Public Schools”..., s. 20-22. 
położenie większego nacisku na zajęcia z wychowania fizycznego, gry zespołowe i zawody sportowe.

Opisując specyfikę Public Schools, Z. Kukulski zwrócił także uwagę na pozostające $\mathrm{w}$ zdecydowanej mniejszości szkoły, które prowadzone były przez katolików. Dokonując charakterystyki szkół: Ampleforth College, Downside School, Douai School, Mount St. Mary's College i Beaumont College ${ }^{35}$, ukazał ich wysoki poziom w porównaniu do szkół będących pod zwierzchnictwem Kościoła anglikańskiego. Należy przy tym dodać, iż dopiero od przyjęcia przez parlament tzw. Universities Test Act w 1871 roku, przedstawiciele innych wyznań religijnych, w tym katolicy, uzyskali prawo do podejmowania studiów na uniwersytetach Oksford, Cambridge i Durham oraz we wszystkich college'ach uniwersyteckich $^{36}$. Faktem jest, że katolicy mogli prowadzić w Anglii własne szkoły dopiero od II połowy XIX wieku. Uwzględnienie szkół katolickich w zestawieniu najbardziej znanych Public Schools dowodzi, że Z. Kukulski dostrzegał ich potencjał, doskonale zdawał sobie sprawę, że poprzez organizację szkół z bardzo wysokim poziomem nauczania możliwe będzie wychowanie elit intelektualnych wśród tej mniejszości wyznaniowej, co znacząco przyczyni się do uzyskania w przyszłości wpływów w parlamencie. Zgodnie z angielską tradycją to właśnie Public Schools najlepiej przygotowywały przyszłą kadrę administracji państwowej, a ukończenie takiej szkoły było przepustką do kariery zawodowej.

Zasługi Z. Kukulskiego w propagowaniu polskich badań porównawczych są niepodważalne. Nie ma znaczenia liczba publikacji, ale ranga podejmowanych problemów badawczych. Wyjątkową wartość prezentuje publikacja pt. „Tak zwane „Public Schools” w Wielkiej Brytanii”, w której autor ukazał ścisły związek komparatystyki edukacyjnej z historią wychowania, podejścia które propagował M. E. Sadler.

35 Tamże, s. 43-47.

36 Universities Test Act 1871, The National Archives, http://www.legislation. gov.uk/ukpga/Vict/34-35/26 (dostęp: 14.02.2021). 


\section{Jan Konopnicki (1905-1980) o eksperymentalnym szkolnictwie w Anglii i Szkocji}

Podobnie jak Z. Kukulski, Jan Konopnicki spędził czasy drugiej wojny światowej w Wielkiej Brytanii. Emigrując z Polski przez Węgry, Francję do Wielkiej Brytanii, miał już doktorat z filozofii uzyskany w 1930 roku na Wydziale Filozoficznym Uniwersytetu Jagiellońskiego oraz doświadczenie zawodowe, zdobyte w pracy jako nauczyciel w gimnazjum i w seminariach nauczycielskich. Będąc żołnierzem II Brygady Strzelców, po klęsce Francji został rozlokowany w Szkocji. Dzięki staraniom gen. Józefa Hallera, który pełnił funkcję kierownika Urzędu Oświaty i Spraw Szkolnych rządu RP w Wielkiej Brytanii, uzyskał zgodę na urlop z wojska i zajął się działalnością oświatową oraz pracą naukową. Nawiązał współpracę ze Zrzeszeniem Nauczycieli Polaków w Wielkiej Brytanii oraz z brytyjskimi pedagogami i psychologami. Na emigracji zajmował się edukacją dorosłych, był głównym organizatorem edukacji polskich nauczycieli na obczyźnie, kierował kursami dokształcającymi i Kursem Pedagogicznym. W 1943 roku założył Studium Pedagogiczne przy Uniwersytecie w Edynburgu, którym kierował do 1946 roku. J. Konopnicki sam również ukończył studia na Uniwersytecie w Edynburgu, po ukończeniu których zajął się pracą naukową ${ }^{37}$. Poza pedagogiką porównawczą prowadził badania nad zastosowaniem szkockich nowatorskich rozwiązań metodologicznych w polskich badaniach pedagogicznych i psychologicznych. Wieloletnia współpraca z Godfreyem Thompsonem i Williamem B. Inglis'em z Moray House Training College for Teachers w Edynburgu oraz środowiskiem szkockich pedagogów i psychologów zaowocowała wieloma jego późniejszymi znakomitymi publikacjami naukowymi, szczególnie w zakresie pedagogiki resocjalizacyjnej ${ }^{38}$.

37 Zob. W. Chmielewski, Jan Konopnicki (1905-1980) - badacz szkolnictwa i organizator edukacji nauczycieli polskich na uchodźstwie, „Studia Paedagogica Ignatiana”, 2018 vol. 21, nr 2, s. 37-62; B. Urban, Jan Konopnicki (1905-1980), w: Złota księga Wydziału Filozoficznego, red. J. Miklaszewska i J. Mizera, Kraków 2000, s. 351-358.

38 W. Chmielewski, Jan Konopnicki..., s. 45. 
Dla J. Konopnickiego prowadzenie badań w obszarze pedagogiki porównawczej było z jednej strony doskonałą okazją do poznania oryginalności rozwiązań angielskiego i szkockiego szkolnictwa, a z drugiej pozwalało mu na wykorzystanie tych doświadczeń w przygotowywaniu koncepcji odbudowy polskiego systemu szkolnictwa po wojnie, przygotowywanej pod patronatem władz oświatowych na uchodźctwie. W opracowaniu tej koncepcji współpracował z Romualdem Niewiakowskim, Wacławem Szomkiem i Amalią Marią Stöcker. J. Konopnicki propagował ideę korzystania z doświadczeń brytyjskich w sferze edukacji, włączając się aktywnie we współpracę Związku Nauczycielstwa Polskiego w Wielkiej Brytanii z Educational Institute of Scotland ${ }^{39}$ (będącym najstarszym związkiem zawodowym nauczycieli na świecie). Kierował pierwszym polskim zespołem naukowym pedagogów komparatystów, który przygotowywał opracowania naukowe na temat szkolnictwa w Wielkiej Brytanii. W ramach tego zespołu oraz w Studium Pedagogicznym jego asystentem był R. Niewiakowski ${ }^{40}$.

Do najważniejszych publikacji J. Konopnickiego z obszaru pedagogiki porównawczej zaliczyć należy rozprawę pt. „Demokratyczne podstawy szkolnictwa szkockiego"41, która wydana została w Londynie w 1942 roku oraz monografię pt. „Eksperymentalne szkolnictwo w Anglii i Szkocji", opublikowaną w $1964^{42}$. J. Konopnicki jest także autorem artykułu pt. Comprehensive Schools i inne eksperymenty selekcyjne $w$ Wielkiej Brytanii, który ukazał się w „Kwartalniku Pedagogicznym” w 1963 roku $^{43}$. Warto podkreślić, że J. Konopnicki wysoko oceniał rozprawę Z. Kukulskiego o angielskich Public Schools, często odwołując się w swoich publikacjach do jego analiz.

J. Konopnicki zapowiadał się jako wnikliwy komparatysta edukacyjny, dostrzegał nowatorstwo rozwiązań stosowanych w angielskich

39 Tamże, s. 42, 44.

40 W. Chmielewski, Przygotowanie kadr..., s. 54-57.

41 J. Konopnicki, Demokratyczne podstawy szkolnictwa szkockiego. Okres przymusu szkolnego, „Nauka i Wychowanie”, Londyn 1942, z. 2, ss. 85.

42 J. Konopnicki, Eksperymentalne szkolnictwo w Anglii i Szkocji, Ossolineum, Wrocław-Warszawa-Kraków 1964.

43 J. Konopnicki, Comprehensive Schools i inne eksperymenty selekcyjne $w$ Wielkiej Brytanii, „Kwartalnik Pedagogiczny”, 1963 nr 1, s. 51-70. 
i szkockich szkołach. Polskie władze oświatowe na uchodźstwie planowały wysłać go na studia w zakresie pedagogiki porównawczej do Stanów Zjednoczonych, ale z uwagi na obowiązki kierownika Studium Pedagogicznego wyjazd ten odroczono ${ }^{44}$. Warto podkreślić, że w pierwszej połowie XX wieku, podobnie jak obecnie, to właśnie amerykańskie uniwersytety znajdowały się w czołówce światowych ośrodków naukowych rozwijających badania w obszarze pedagogiki porównawczej. Można zaryzykować stwierdzenie, że J. Konopnicki miał szansę na bycie pionierem polskiej pedagogiki porównawczej. Po powrocie do Polski, po zakończeniu wojny rozwijał on jednak badania w obszarze pedagogiki eksperymentalnej i resocjalizacyjnej. Ograniczył swoją działalność naukową w obszarze pedagogiki porównawczej, zapewne z uwagi na trudną sytuację polityczną w PRL-u i obowiązującą cenzurę. Jak podkreślali w swoich wspomnieniach o J. Konopnickim jego uczniowie, prezentował on zawsze niezależną postawę światopoglądową. Publikowanie więc prac naukowych dotyczących edukacji w Anglii i Szkocji, a szczególnie wskazywanie na pozytywne aspekty niektórych rozwiązań organizacyjnych, bez odniesień do uznawanych wówczas za najlepsze osiągnięć szkolnictwa radzieckiego, mogło być źle widziane. Nie mniej jednak, doświadczenie i wiedzę, jakie zdobył J. Konopnicki w renomowanych ośrodkach naukowych w Anglii i Szkocji, wykorzystał później w kraju w przygotowaniu młodych pracowników naukowych, kształceniu nauczycieli, ale także i w pracy z dziećmi w specjalistycznych placówkach wychowawczych i leczniczych.

Oryginalność angielskiego i szkockiego szkolnictwa J. Konopnicki najpełniej zaprezentował w wspomnianej już wcześniej monografii pt. „Eksperymentalne szkolnictwo w Anglii i Szkocji”. Już we wstępie zaznaczył, że eksperymenty edukacyjne w tych częściach Zjednoczonego Królestwa są szczególnie interesujące i powinny zainteresować polskiego czytelnika. Przytoczył również opinie niektórych brytyjskich autorów, którzy skłonni byli twierdzić, że jedną z głównych zasad brytyjskiego szkolnictwa jest eksperymentalizm. Sam jednak zwrócił uwagę na fakt, iż w brytyjskim szkolnictwie w pierwszej połowie XX wie-

${ }^{44}$ W. Chmielewski, Jan Konopnicki..., s. 50-51. 
ku współegzystuje konserwatywne podejście do wielu zasad nauczania oraz wiele nowoczesnych rozwiązań i prób, których jednak nikt nie kontroluje, ani nie rejestruje. Na dowód przytoczył przykłady głośnych eksperymentów edukacyjnych, typowo angielskich, takich jak eksperyment w Leicester, który nie doczekał się opracowania naukowego w literaturze pedagogicznej. J. Konopnicki wiele uwagi poświęcił również swoistym eksperymentom pedagogicznym, jakie stosowane były w szkole-szpitalu dla dzieci epileptycznych w Lingfield oraz w szkole dla dzieci opóźnionych w nauce w Birmingham ${ }^{45}$. Podane przykłady brytyjskich placówek edukacyjnych miały na celu zaznajomienie polskich nauczycieli z oryginalnymi rozwiązaniami, jakie stosowane były w Wielkiej Brytanii oraz zachęcenie do podjęcia prób zorganizowana podobnych szkół również w Polsce.

J. Konopnickiego można uznać za znawcę angielskiego i szkockiego szkolnictwa, poza doskonałą znajomością brytyjskiej literatury pedagogicznej, organizacji angielskich i szkockich zakładów kształcenia nauczycieli, specyfiki studiów w Uniwersytecie w Edynburgu, prowadził także badania terenowe, odwiedzał szkoły eksperymentalne, prowadził obserwacje naukowe oraz przeprowadzał wywiady $\mathrm{z}$ kierownikami i nauczycielami z tych placówek. Podkreślał, że publikowanie opracowań w zakresie pedagogiki porównawczej: może stanowić pewien wkład $w$ nie bardzo bogata naszą pedagogikę porównawcza ${ }^{46}$. Celem tego typu publikacji było przede wszystkim informowanie polskich nauczycieli o eksperymentach pedagogicznych, jakie stosowane były z powodzeniem zagranicą. Przy czym sam J. Konopnicki zaznaczał, że nie wszystkie brytyjskie eksperymenty nadają się do naśladowania w Polsce. Edukacja była i jest domeną narodową, a istniejące w poszczególnych systemach oświatowych różnice, wynikają właśnie z odmienności tradycji i kultury danych narodów. J. Konopnicki doskonale zdawał sobie sprawę z tych różnic, rozumiał też, że w PRL-u promowanie zachodnioeuropejskich nowatorskich rozwiązań edukacyjnych, opartych na coraz większej demokratyzacji szkolnictwa nie będzie możliwe.

\footnotetext{
45 J. Konopnicki, Eksperymentalne szkolnictwo..., s. 9-10, 119-148.

46 Tamże, s. 10.
} 
Bardzo ciekawie przedstawia się analiza angielskich Public Schools, której dokonał J. Konopnicki. Public Schools uważał on za swoiste szkoły eksperymentalne, tak odmienne od konwencjonalnych szkół, a przy tym ekskluzywne, elitarne i wywołujące wiele kontrowersji, szczególnie w społeczeństwach kontynentalnej Europy. J. Konopnicki podkreślał, że Public Schools są instytucją typowo angielską, przeznaczoną dla dzieci najbogatszych warstw społecznych, wymagają bowiem wniesienia bardzo wysokich opłat za czesne. Dla J. Konopnickiego wyjątkiem, mającym również charakter eksperymentalny było dopuszczenie do Public Schools tzw. uczniów funduszowych, a celem samego eksperymentu pedagogicznego miało być wzmocnienie angielskich elit o przedstawicieli z klas niższych. J. Konopnicki podkreślał, że: Public Schools to instytucje, które przez jednych uważane sa za coś najlepszego $w$ szkolnictwie brytyjskim, przez drugich zaś sa potępiane jako symbol reakcji $i$ wstecznictwa ${ }^{47}$. Wyraził tym samym pogląd, iż szkoły te są dla Brytyjczyków powodem do dumy, są instytucjami, które wychowują przyszłych, światłych obywateli imperium brytyjskiego, odpowiedzialnych w przyszłości za politykę kraju. Zaznaczał przy tym, że krytycy Public Schools nie rozumieją angielskiego przywiązania do tradycji edukacyjnych, przez co oskarżają kierownictwo i nauczycieli tych szkół o wstecznictwo i nadmierne selekcje szkolne.

Przedstawiając historię angielskich Public Schools, podkreślił, że wbrew nazwie szkoły te nie są placówkami publicznymi, a instytucjami elitarnymi, do których dostęp jest szczególnie utrudniony, a dla dzieci z uboższych rodzin właściwie niemożliwy. J. Konopnicki zwrócił uwagę, że elitarne szkoły średnie, sięgające tradycjami epoki średniowiecza, miewały wzloty i upadki. Przemiany społeczne, a zwłaszcza rewolucja przemysłowa i rozwój kapitalizmu wymusiły niejako zmiany w sposobie funkcjonowania Public Schools. Pionierami nowego wychowania w tych placówkach w pierwszej połowie XIX wieku byli znani pedagodzy: dyrektor szkoły w Rugby - dr Thomas Arnold oraz dyrektor szkoły w Uppingham i założyciel Konferencji Dyrektorów - Edward Thiring48 ${ }^{48}$. Dzięki T. Arnoldowi wiele innych Public Schools zreformowało swoje progra-

\footnotetext{
47 Tamże, s. 36-37.

48 Tamże, s. 38-41.
} 
my nauczania, rezygnując z dominacji klasycznego wychowania i włączając zajęcia z wychowania fizycznego, sport i gry zespołowe. Z kolei niewątpliwą zasługa E. Thiringa było wprowadzenie w tych szkołach zajęć warsztatowych oraz propagowanie indywidualnego podejścia do każdego ucznia. Za klucz do sukcesu angielskich Public Schools J. Konopnicki uznawał: zapewnienie młodzieży możliwie najlepszych warunków do życia i nauki w szkołach z internatem, wychowanie przez ćwiczenia fizyczne i sport, wychowanie artystyczne, skauting oraz bardzo wysoki poziom zajęć dydaktycznych. Te pięć elementów składało się na „ducha” Public Schools, czyli specjalne metody wychowania, jakie stosowano w tych szkołach. J. Konopnicki z uznaniem podkreślał, że za sukcesem Public Schools stoi kadra pedagogiczna, złożona z nauczycieli posiadających tytuły naukowe, zdobyte przede wszystkim na najlepszych angielskich uniwersytetach Oksfordzie i Cambridge. Wybitni nauczyciele otrzymują za swoją pracę w Public Schools należyte, wysokie wynagrodzenie, niejednokrotnie przewyższające kilka razy pensje nauczycieli średnich szkół samorządowych ${ }^{49}$.

Znajomość angielskiego i szkockiego szkolnictwa, rozumienie specyfiki działalności elitarnych szkół średnich z internatem, różnego rodzaju eksperymentalnych placówek wychowawczo-oświatowych pozwoliły J. Konopnickiemu na stworzenie własnej koncepcji kształcenia nauczycieli w Polsce po zakończeniu II wojny światowej. Nie wszystkie pomysły J. Konopnickiego miały szansę na realizację w PRL-u, nie mniej jednak odegrał on znaczącą rolę $\mathrm{w}$ wychowaniu swoich następców oraz przygotowaniu zawodowym swoich studentów - przyszłych nauczycieli.

J. Konopnicki prezentując oryginalne angielskie i szkockie rozwiązania szkolnictwa eksperymentalnego, odwoływał się jednocześnie do niezwykle bogatego dorobku brytyjskiej literatury pedagogicznej w zakresie pedagogiki eksperymentalnej i różnych dziedzin psychologii, podkreślając jednocześnie niedostatek opracowań w zakresie teorii wychowania. Jednym z celów prowadzonych przez niego badań było tłumaczenie na język polski głośnych wówczas dzieł pedagogicznych,

49 Tamże, s. 40-43. 
takich jak rozprawa Jamesa Stivena Rossa pt. Groundwork of Educational Theory ${ }^{50}$, wydanej w Londynie w 1942 roku. Tłumaczenie tej publikacji na język polski nie doczekało się jednak wydania drukiem. Rozpatrując zjawiska edukacyjne w Anglii i Szkocji, J. Konopnicki ukazywał te rozwiązania w szerokim kontekście społeczno-kulturowym, w paradygmacie humanistycznym. Takie podejście badawcze $\mathrm{w}$ pedagogice porównawczej głosił brytyjski komparatysta edukacyjny M. E. Sadler.

\section{Reformy angielskiego szkolnictwa po II wojnie światowej w ocenie Karola Kotłowskiego (1910-1988)}

Dla znanego filozofa, teoretyka i historyka wychowania, jakim był Karol Kotłowski, badania i analizy w zakresie pedagogiki porównawczej były jedynie jednym z wielu przedsięwzięć badawczych, jakie podejmował w swojej pracy naukowej. K. Kotłowski publikował rozprawy na temat współczesnych mu wpływów myśli filozoficznej w naukach o wychowaniu, oczywiście w graniach dopuszczalnych przez cenzurę, ale też głosił niezależne sądy naukowe oparte na znajomości literatury pedagogicznej z Zachodu, które nie były dostępne ani w oryginale, ani tym bardziej w języku polskim. Sprzeciwiał się izolacjonizmowi polskiej pedagogiki naukowej od dokonań pedagogiki krajów Europy Zachodniej. Ponadto cenił sobie wolność i nigdy nie zaakceptował narzuconego polskiemu społeczeństwu ustroju ${ }^{51}$. Podejście badawcze K. Kotłowskiego do pedagogiki porównawczej w dużej mierze zostało ukształtowane przez jego mistrza - Sergiusza Hessena, który z kolei współpracował z wybitnym komparatystą edukacyjnym Nicholasem Hansem $^{52}$. K. Kotłowski był zwolennikiem prowadzenia badań komparatystycznych w paradygmacie humanistycznym, ze szczególnym uwzględnieniem analiz historycznych.

50 J.S. Ross, Groundwork of Educational Theory, G.G. Harrap\& Co., Londyn 1942.

51 B. Śliwerski, Analiza prądów wychowania według K. Kotłowskiego, w: Idee pedagogiki filozoficznej, red. S. Sztobryn, B. Śliwerski, Łódź 2003, s. 12-14.

52 A. Włoch, J. Wojniak, Global field, local approach $-20^{\text {th }}$ century Polish education comparativists and their works, "SHS Web of Conferences" 2019, vol. 66, p. 1-10, https://doi.org/10.1051/shsconf/20196601031 
K. Kotłowski zajmował się pedagogiką porównawczą w ścisłym związku z historią wychowania. W jego dorobku naukowym, traktującym o szkolnictwie angielskim znajduje się jedna ważna monografia pt. „Szkoła angielska po drugiej wojnie światowej”"53, będąca rezultatem jego 3-miesięcznego pobytu w Anglii, wydana w 1960 roku oraz kilka artykułów, które ukazały się w czasopismach pedagogicznych ${ }^{54}$. Zainteresowanie historią angielskiego szkolnictwa pozwoliło mu na ukazanie ważnych przemian edukacyjnych, jakie zaszły w tym kraju, aż do uchwalenia Aktu Edukacyjnego w 1944 roku. Poprzez liczne odwołania do historii wychowania i myśli pedagogicznej w Anglii oraz w kontynentalnej Europie, nakreślił on ważne etapy w rozwoju systemu edukacji angielskiego społeczeństwa. Szczególnie interesowały go przemiany, jakie zachodziły w angielskim systemie szkolnym oraz w kształceniu nauczycieli w XIX i XX wieku. Niezwykle interesujące $\mathrm{w}$ tych analizach są porównania do osiągnięć w tym zakresie polskiego społeczeństwa, szczególnie podkreślanie pionierskich reform Komisji Edukacji Narodowej.

Ukazując historię edukacji w Anglii, K. Kotłowski zwracał uwagę na fakt, iż ministerstwo wychowania powstało w Anglii dopiero na mocy Aktu Edukacyjnego z 1944 roku $^{55}$, czyli ponad 170 lat później, aniżeli KEN. W odróżnieniu od innych państw europejskich, angielskie szkolnictwo przez długie stulecia funkcjonowało poza jakąkolwiek kontrolą państwa, sprawami oświaty zajmowały się kościoły, stowarzyszenia religijne i charytatywne, związki kupieckie oraz prywatne osoby. Zdaniem K. Kotłowskiego sytuacja ta spowodowała, że w angielskim społeczeństwie zrodził się zupełnie inny stosunek do szkoły i oświaty, aniżeli w państwach kontynentalnej Europy. W myśli angielskiego liberalizmu, edukacja niższych warstw społecznych była raczej aktem

53 K. Kotłowski, Szkoła angielska po drugiej wojnie światowej, PZWS, Warszawa 1960.

54 Zob.: K. Kotłowski, Współczesne tendencje rozwojowe szkolnictwa angielskiego, „Kwartalnik Pedagogiczny” 1958, nr 3, s. 39-66; K. Kotłowski, Ideologiczne podstawy reformy szkolnictwa w Anglii w 1944 roku, „Chowanna” 1962, nr 1, s. $36-48$.

55 Zob.: Education Act 1944, legislation.gov.uk,https://www.legislation.gov. uk/ukpga/Geo6/7-8/31/contents 
miłosierdzia grup uprzywilejowanych wobec tych najbiedniejszych ${ }^{56}$. Dostrzegał więc K. Kotłowski ścierające się w Anglii dwa nurty konserwatywny i liberalny, których zwolennicy mieli zupełnie odmienną wizję rozwoju systemu oświaty w Zjednoczonym Królestwie.

Zadając sobie doskonale sprawę, jak trudno jest opisać historię i rozwój angielskiego szkolnictwa, K. Kotłowski zaznaczał, że takie przedsięwzięcie wymagałoby opisania z osobna historii każdego typu szkół, jakie od wczesnego średniowiecza działają na Wyspach Brytyjskich. Dokonał więc selekcji faktów, które w możliwie najprostszy sposób tłumaczyły, jaką drogę musiało przejść angielskie społeczeństwo, aby zapewnić wszystkim dzieciom dostęp do edukacji. Przygotowując się do napisania monografii poświęconej szkole angielskiej, K. Kotłowski zwiedzał różne typy szkół, przeprowadzał wywiady z kadrą nauczycielską, analizował dokumenty i prowadził obserwacje. Usprawiedliwiał jednocześnie swoje stanowisko w kwestii oceny zjawisk oświatowych, gdyż w wielu przypadkach niemal zawsze nasuwało mu się oczywiste porównanie do polskiej szkoły. Jego intencją było przygotowanie opracowania dla polskich nauczycieli, którzy dzięki możliwości zaznajomienia się ze specyfiką angielskiego systemu oświaty, mieli okazję do wykorzystania tych doświadczeń w celu poprawienia sytuacji w naszym kraju ${ }^{57}$. Wiele uwagi poświęcił w swojej pracy K. Kotłowski angielskim reformom oświatowym z drugiej połowy XIX i pierwszej połowy XX wieku. Dostrzegał trudności angielskiego szkolnictwa jeszcze przed wybuchem II wojny światowej, wynikające z niedostatecznej liczby wykwalifikowanych nauczycieli. Wskazał na Akt Edukacyjny z 1944 roku, jako na najważniejszą ustawę o systemie edukacji w pierwszej połowie XX wieku, która ustaliła trzy podstawowe sektory szkolnictwa, stojące przed studiami uniwersyteckimi: podstawowy (primary), średni (secondary) oraz obejmujący kształcenie dorastającej młodzieży (furthereducation). Ponadto ustawa ta określiła, że obowiązek szkolny rozpoczyna się po ukończeniu przez dziecko piątego roku życia i trwa dziesięć lat. Podtrzymano natomiast dotychczasowy podział angielskich szkół na państwowe i prywatne. Ze względu na

\footnotetext{
56 K. Kotłowski, Szkoła angielska..., s. 4.

57 Tamże, s. 6-7.
} 
różnice w programach kształcenia działały cztery typy szkół: szkoły gramatyczne (grammar schools), Public Schools, szkoły techniczne oraz nowoczesne szkoły średnie ${ }^{58}$.

Podobnie, jak Z. Kukulski i J. Konopnicki autor poświęcił sporo uwagi angielskim Public Schools, pisząc, że: tworza bowiem zupetnie zamknięte autonomiczne republiki - wyspy $w$ morzu angielskiego szkolnictwa ${ }^{59}$. Trudno nie odnieść wrażenia, że K. Kotłowski dostrzegał przywiązanie angielskiego społeczeństwa do tradycji, w tym również do dumy z Public Schools, które odpowiedzialne były za elitarne wykształcenie i wychowanie przyszłych rządzących. Działalność tych szkół kwitował stwierdzeniem: „public schools” wydaja konserwatystów, szkoty elementarne - labourzystów ${ }^{60}$. Słusznie zauważał także, że Public Schools są obok skautingu jednymi z największych osiągnięć edukacyjnych angielskiego szkolnictwa. Doszukując się w polskiej historii edukacji szkół, pełniących choć przez pewien okres rolę angielskich Public Schools, wskazywał na działalność Collegium Nobilium Stanisława Konarskiego.

Podsumowując swoje charakterystyki angielskiego szkolnictwa, K. Kotłowski zastrzegał, że dalszy rozwój edukacji w tym kraju zależeć będzie od tego, która partia będzie w danym momencie przy władzy oraz jak się ułożą stosunki społeczne i gospodarcze. Ważnym czynnikiem przyszłych reform oświatowych w dalszym ciągu będzie jednak ogromne przywiązanie Anglików do tradycji.

\section{Zakończenie}

Dla wielu polskich pedagogów z czasów II wojny światowej oraz lat 60. XX wieku badania komparatystyczne były nowością. Uzupełnianie analiz komparatystycznych badaniami historyczno-oświatowymi było wówczas charakterystycznym podejściem badawczym w polskiej pedagogice porównawczej, którego wielkim zwolennikiem był przede wszystkim B. Nawroczyński. Zaszczepił on na gruncie polskiej pedago-

\footnotetext{
58 Tamże, s. 37-43, 55-84.

59 Tamże, s. 61.

60 Tamże, s. 65.
} 
giki naukowej koncepcję metodologiczną wybitnego brytyjskiego komparatysty M.E. Sadlera.

Sam fakt podjęcia próby ukazania złożoności angielskiego systemu oświatowego przez polskich pedagogów, świadczy o ich wysokich kompetencjach badawczych, bardzo dobrej znajomości nie tylko historii wychowania w Anglii, ale także znajomości anglosaskiej literatury pedagogicznej oraz co niezwykle istotne, znajomości angielskiej kultury. Jak pisał K. Kotłowski: zrozumienie angielskiego systemu szkolnego jest rzecza trudną nawet dla Brytyjczyka znającego swój kraj i jego dziwaczne, z naszego punktu widzenia, prawa i obyczaje, a dla obcokrajowca trudności te jeszcze się potęgują i na pierwszy rzut oka sq nie do pokonania ${ }^{61}$.

Warto podkreślić, że czasy emigracji w trakcie II wojny światowej tacy pedagodzy, jak Z. Kukulski i J. Konopnicki wykorzystali na zgłębienie wiedzy o specyfice angielskiego i szkockiego szkolnictwa oraz zaprezentowanie tych oryginalnych rozwiązań oświatowych w publikacjach, których odbiorcami mieli być przede wszystkim polscy nauczyciele. Znajomość systemów edukacyjnych funkcjonujących w Wielkiej Brytanii miała być wykorzystana przy tworzeniu koncepcji odbudowy polskiego szkolnictwa po zakończeniu wojny. Temu celowi przyświecała również działalność J. Konopnickiego i Z. Kukulskiego oraz wielu innych nauczycieli, odpowiedzialnych za przygotowanie zawodowe polskich nauczycieli na obczyźnie. Znaczenie problemów edukacyjnych oraz reform, jakie miały miejsce w I połowie XX wieku w Anglii mogły być z powodzeniem wykorzystane w polskim szkolnictwie. Ponadto rozwój badań porównawczych skłaniał polskich pedagogów i nauczycieli do tworzenia nowoczesnych instytucji oświatowych, a szczególnie szkół, które odpowiadałyby na rozmaite potrzeby swoich uczniów. Niewątpliwie znajomość zagranicznych systemów edukacyjnych sprzyjała realizacji tych celów.

61 Tamże, s. 3. 


\section{Bibliografia:}

\section{Źródła}

Education Act 1944. The National Archives.https://www.legislation.gov.uk/ ukpga/Geo6/7-8/31/contents (dostęp: 17.05.2021).

Universities Test Act 1871. The National Archives.

http://www.legislation.gov.uk/ukpga/Vict/34-35/26 (dostęp: 14.02.2021).

Szwejkowski, Wojciech. „Uwagi nad wyższymi szkołami polskimi w porównaniu do niemieckich". Warszawa 1818, w: Źródła do dziejów wychowania i szkolnictwa $w$ Polsce z doby Izby Edukacji Publicznej 1807-1812, red. Z. Kukulski, Lublin 1931, s. 14-63.

http://dlibra.umcs.lublin.pl/dlibra/docmetadata?id=1430\&from=publication 9 (dostęp: 14.02.2021).

\section{Opracowania}

Bereday, George Z. F. Comparative Method in Education.New York: Holt, Reinhart and Winston, Inc., 1964.

Epstein, Erwin H. „Is Marc-Antoine Jullien de Paris the 'father' of comparative education?". Compare: A Journal of Comparative and International Education (2017) no 47, vol. 3, p. 317-331.

Chmielewski, Witold. Przygotowanie kadr oświatowych na uchodźstwie w latach 1941-1948. Warszawa: IHN PAN, 2013.

Chmielewski, Witold. „Jan Konopnicki (1905-1980) - badacz szkolnictwa i organizator edukacji nauczycieli polskich na uchodźstwie". Studia Paedagogica Ignatiana (2018) vol. 21, nr 2: 37-62.

Dobrzański, Jan. „Wspomnienie o Zygmuncie Kukulskim”. Roczniki Humanistyczne (1950-1951) nr 2-3: 357-365.

Draus, Józef. „Zygmunt Kukulski (1890-1944)”. Roczniki Nauk Społecznych (1989) t. XVII, z. 2: 5-19.

Dziewulak, Dobromir.Polityka oświatowa Wspólnoty Europejskiej. Warszawa: Wydawnictwo Akademickie „Żak”, 1995.

Dziewulak, Dobromir.Systemy szkolne Unii Europejskiej. Warszawa: Wydawnictwo Akademickie „Żak”, 1997.

Gmerek, Tomasz. Edukacja i nierówności społeczne. Studium porównawcze na przykładzie Anglii, Hiszpanii i Rosji. Kraków: Oficyna Wydawnicza Impuls, 2011. 
Gromkowska-Melosik, Agnieszka.Elitarne szkolnictwo średnie. Między reprodukcją społeczno-kulturową a ruchliwością konkurencyjną. Poznań: Wydawnictwo Naukowe UAM, 2015.

Haller, Józef. „Zamiast przedmowy”. W: Kukulski, Zygmunt. „Tak zwane „Public Schools" w Wielkiej Brytanii". Nauka i Wychowanie (1942) z. 1. Londyn: Wydawnictwo Urzędu Oświaty i Spraw Szkolnych, s. 5.

https://pbc.gda.pl/dlibra/publication/39163/edition/65418/content?\&meta-lang=pl (dostęp: 13.02.2021).

Hejwosz-Gromkowska, Daria. Edukacja obywatelska we współczesnej Anglii: studium socjopedagogiczne. Poznań: Wydawnictwo Naukowe UAM w Poznaniu, 2019.

Konopnicki, Jan. „Comprehensive Schools i inne eksperymenty selekcyjne w Wielkiej Brytanii”. Kwartalnik Pedagogiczny (1963) nr 1: 51-70.

Konopnicki, Jan. „Demokratyczne podstawy szkolnictwa szkockiego. Okres przymusu szkolnego". Nauka i Wychowanie (1942), Londyn, z. 2, ss. 85.

Konopnicki, Jan. Eksperymentalne szkolnictwo w Anglii i Szkocji. Wrocław-Warszawa-Kraków: Zakład Narodowy im. Ossolińskich, 1964.

Kotłowski, Karol. „Ideologiczne podstawy reformy szkolnictwa w Anglii w 1944 roku". Chowanna (1962) nr 1: 36-48.

Kotłowski, Karol. Szkoła angielska po II wojnie światowej. Warszawa: PZWN, 1960.

Kotłowski, Karol. „Współczesne tendencje rozwojowe szkolnictwa angielskiego". Kwartalnik Pedagogiczny (1958) nr 3: 39-66.

Kukulski, Zygmunt. „Brytyjski ideał wychowawczy”. Przegląd Pedagogiczny 1 (1941): 6-8.

Kukulski, Zygmunt. „Tak zwane „Public Schools” w Wielkiej Brytanii”. Nauka i Wychowanie (1942) z. 1. Londyn: Wydawnictwo Urzędu Oświaty i Spraw Szkolnych, ss. 69. https://pbc.gda.pl/dlibra/publication/39163/ edition/65418/content?\&meta-lang=pl (dostęp: 09.02.2021).

Loria, Jadwiga. Szkolnictwo w Anglii i jego tradycje. Wrocław-Warszawa-Kraków: Zakład Narodowy im. Ossolińskich, 1964.

Matlakiewicz, Alina. Edukacja dorostych $w$ Wielkiej Brytanii, Wydawnictwo Akademickie „Żak”, Warszawa 2003.

Miąso, Józef. Geneza i rozwój uniwersytetów powszechnych w Anglii. Rozprawy z Dziejów Oświaty (1984) t. 26: 109-140.

Miąso, Józef. „Oświata dorosłych w Wielkiej Brytanii pierwszej połowy XIX wieku". Rozprawy z Dziejów Oświaty (1980) t. 23: 101-124. 
Miąso, Józef. „Szkolnictwo w XIX-wiecznej Europie i początki pedagogiki porównawczej w Anglii". Rozprawy z Dziejów Oświaty (2009) t. 46: 85-146.

Mitter Wolfgang. "The Comparative Education Society in Europe (CESE)”. W: Common Interests, Uncommon Goals. Histories of the World Council of Comparative Education Societies and its Members, V. Masemann, M. Bray i M. Manzon (eds.). Dordrecht: Comparative Education Research Centre The University of Hong Kong, Springer, 2008, p. 116-126.

Mońka-Stanikowa, Anna. „Bogdan Nawroczyński - Człowiek i Dzieło”, w: Bogdan Nawroczyński - uczony, humanista, wychowawca, red. naukowa A. Mońka-Stanikowa, S. Mieszalski, A. A. Kotusiewicz.Warszawa: Wydawnictwo „Żak”, 1996, s. 10-24.

Nawroczyński, Bogdan. „Pedagogika porównawcza”. Kwartalnik Pedagogiczny (1962) nr 1: 29-47.

Nawroczyński, Bogdan. „Przedmiot i metoda pedagogiki porównawczej”. Studia Pedagogiczne (1972) t. XXVI: 5-18.

Nawroczyński, Bogdan. „Przegląd czasopisma: “International Review of Education" ed. by UNESCO, Institute for Education, Hamburg, vol. VII, 1961". Kwartalnik Pedagogiczny (1964) nr 3 (33): 269-271.

Nawroczyński, Bogdan. „Przegląd czasopisma: “International Review of Education” 1963". Kwartalnik Pedagogiczny (1966) nr 3 (41): 255-257.

Nawroczyński, Bogdan. „Recenzja: John F. Cramer and George S. Browne, Contemporary Education. A Comparative Study of National Systems, New York 1956". Kwartalnik Pedagogiczny (1958) nr 3 (9): 194-195.

Nawroczyński, Bogdan. „Recenzja: A. Kerr, Schools of Europe Canterbury Press, Westminister, Maryland 1961". Kwartalnik Pedagogiczny (1963) nr 2 (28): 255-257.

Nowakowska-Siuta, Renata. Pedagogika porównawcza. Problemy, stan badań i perspektywy rozwoju. Kraków: Oficyna Wydawnicza Impuls, 2014.

Pachociński, Ryszard. Współczesne systemy edukacyjne. Warszawa: IBE, 2000.

Potulicka, Eugenia. Geneza reformy edukacji w Anglii $i$ Walii z roku 1988. Poznań-Toruń: „Edytor”, 1993.

Potulicka, Eugenia. „System edukacji w Wielkiej Brytanii”. W: Systemy edukacji $w$ krajach europejskich, red. naukowa E. Potulicka, D. Hildebrandt-Wypych, C. Czech-Włodarczyk. Kraków: Oficyna Wydawnicza Impuls, 2012, s. 341-384.

Rabczuk, Wiktor. Polityka edukacyjna Unii Europejskiej na tle przemian w szkolnictwie krajów członkowskich. Warszawa: IBE, 1994. 
Rabczuk, Wiktor. Polityka edukacyjna Unii Europejskiej wobec imigrantów oraz mniejszości narodowych i etnicznych. Warszawa: IBE, 2002.

Rabczuk, Wiktor. Szkolnictwo prywatne $w$ Europie Zachodniej i $w$ Polsce. Warszawa: Wydawnictwa Szkolne i Pedagogiczne, 1992.

Ross, James Stiven. Groundwork of Educational Theory. Londyn: G.G. Harrap \& Co.,1942.

Suchodolski, Bogdan. „Pedagogika porównawcza i polityka oświatowa”. Studia Pedagogiczne (1972) t. XXVI. Studia z Pedagogiki Porównawczej: 19-27.

Śliwerski, Bogusław. „Analiza prądów wychowania według K. Kotłowskiego”, w: Idee pedagogiki filozoficznej, red. Sławomir Sztobryn, Bogusław Śliwerski, 11-22. Łódź: Wydawnictwo Uniwersytetu Łódzkiego, 2003.

Śliwerski, Bogusław. „Ponadczasowa doniosłość pedagogiki porównawczej Bogdana Nawroczyńskiego". Studia Edukacyjne (2018) nr 47: 21-32.

Urban, Bronisław. „Jan Konopnicki (1905-1980)”, w: Złota księga Wydziału Filozoficznego, red. J. Miklaszewska, J. Mizera, 351-358. Kraków: Księgarnia Akademicka, 2000.

Włoch, Anna, Wojniak, Justyna. 2019. „Global field, local approach $-20^{\text {th }}$ century Polish education comparativists and their works". SHS Web of Conferencesvol. 66: p. 1-10, https://doi.org/10.1051/shsconf/20196601031

Wołk, Katarzyna. „Listy Zygmunta Kukulskiego z okresu szkockiego źródłem badań biograficznych". Biografistyka Pedagogiczna R. 2, nr 1 (2017): 395-405 .

Wołk, Katarzyna. Zygmunt Bolesław Kukulski (1890-1944). Pedagog, wychowawca i społecznik. Lublin: Wydawnictwo EPISTEME, 2018. 